\title{
The Institutionalization of New Public Management (NPM) on Indonesia Healthcare and Social Security Agency
}

\author{
Septian Bayu Kristanto ${ }^{1^{*}}$, Neng Ida Soniawati ${ }^{2}$, Ahmad Hambali $^{3}$, Siti Rahma Siregar ${ }^{3}$ \\ ${ }^{I}$ Faculty of Business and Economics, Krida Wacana Christian University, Jakarta, Indonesia \\ ${ }^{2}$ Senior High School 1 (State-Owned), Babakan, Madang, Bogor, Indonesia \\ ${ }^{3}$ Faculty of Business and Economics, University of Indonesia, Depok, Indonesia \\ *Corresponding author.Email: septian.bayu@ukrida.ac.id
}

\begin{abstract}
This research offers an insight into the main challenges and adverse effects of the restructuring of the primary health-sector in Indonesia. The Authors also set-up a universal-term of Healthcare and Social Security Agency called "Badan Penyelenggara Jaminan Sosial (BPJS) Kesehatan" in Indonesian. This "BPJS Kesehatan" (or BPJS) expands the scope of healthcare, confronts crucial challenges and unexpected implications, including budgetary deficits, resistance from medical professionals, and the propensity of decision-makers. In the New Public Management (NPM) process, we found that the introduction of the insurance program was primarily motivated by the interests of decision-makers and international bodies to the detriment of a sustainable national healthcare system. This report contributes to the health-policy change literature and contradicts the basic values of healthcare programs. The survival of the medical profession in Indonesia is also under attack. The Authors provides a variety of recommendations for the adoption of better policies in this area in developed countries. Keywords: BPJS Kesehatan, Healthcare and Social Security, Indonesia, Public, Government
\end{abstract}

\section{INTRODUCTION}

The institutionalization of the New Public Management (NPM) of the healthcare system has provided unintended gains to individuals with higher wages and better differential coverage for healthcare [1], and failure to increase care efficiency, equity and efficacy [2]. The implementation of NPM in this sector has raised healthcare practitioners' anxiety, led clinical and non-clinical workers to discord, and helped physicians and social activists to resist [3].

NPM reforms were enforced in many fields in the healthsector [4]. The decentralization of the management of public hospitals in Indonesia has been introduced since 2001 as well as the greater responsibility for the administration and financing of local public hospitals by local municipal governments. With decentralization in mind, the public hospitals were encouraged to recognize companies to allow them to raise income from the patients' fees portion. More major reforms were carried out with the formation of the Indonesia Healthcare and Social Security Agency or "Badan Penyelenggara Jaminan Sosial Kesehatan" (BPJS Kesehatan, or called BPJS only) since 2014 [5].

The NPM has had extensive consequences for national healthcare policy and these studies primarily concentrated on developing economies [6]. Neo-liberalism prioritizes loans to these institutions at the cost of education and medical services in the developing world. In several African and South American countries and Greece, these diseases caused severe problems lately [7]-[10]. As discussed above, a large part of health policy has traditionally only involved technical aspects of policy material, rather than the mechanism of policy adoption [11]. This research adds to the literature on health policy by illustrating the impact of economic and political stories on universal insurance in the Southeast Asian countries, such as Indonesia's developing economy.

From the topic mentioned above, the following research questions emerged in this research: (1) How does the BPJS health infrastructure in Indonesia affect NPM? (2) In the institutionalization of BPJS, what are the structural challenges in Indonesia? (3) What should be the strategic choices for creating a healthier and effective national healthcare system to fulfil the goals of BPJS?

This research adds to the scholarly literature on health policy-making internationally by strengthening the nature and structural complexity of an ongoing health sector analysis in Indonesia. Moreover, this article provides useful insights, particularly for developing and emerging economies, for policy-makers and academics. In realistic terms, this analysis involves the deployments of BPJS, as general healthcare programs in Indonesia are outstanding. 


\section{LITERATURE REVIEW}

\subsection{NPM Concepts on Health-Insurance Services}

The major influence of the economic and financial crisis has been on public-sector improvements in the developed markets, and it is not possible to ignore the role of international organizations in shaping these reforms. As their industry is primarily driven by neo-liberalism and profit-making, the government's spending on education and health declines in Africa, South America, Indonesia and Greece [7]-[10]. In our perspective, the meaning and ramifications of how BPJS operates in Indonesia should be rigorously studied, both oligarchical politics and neoliberalism, as promoted by international institutions.

With BPJS in operation, Indonesia has made steady progress with the start of BPJS in 2014 and 165 million BPJS members; the total number of members has grown-up to 220 million by 2019, as seen in Figure 1. Also, BPJS software is currently undergrowth. Researchers accepted that BPJS is the world's first single-payer insurance system [12]. Through the introduction of BPJS in 2014, Indonesia has made steady progress with 165 million BPJS members; by 2019 it increased to a total of 220 million, which appears in Figure 1. BPJS was introduced with the NPM-based health-insurance program. Researchers deem BPJS to be the world's first single-payer insurance scheme. These ideals have also been reflected in its tasks [10]: enhance fairservices standards; expand the number of insurance members to cover all Indonesian people; ensure the feasibility of the insurance program; enhance the regulation and enforcement for the programmed BPJS; as well as improving the BPJS's capacity and governance.

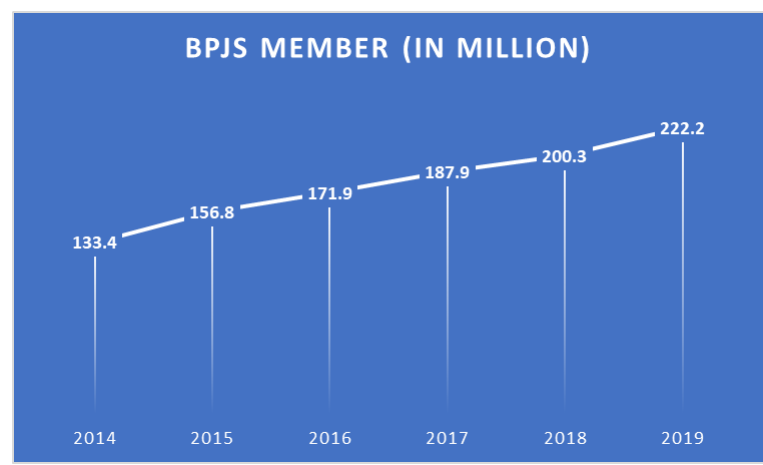

Figure 1 BPJS Members

Source: https://bpjs-kesehatan.go.id/bpjs/

The association also controls the billing of insurance services, such as hospitals and other health insurers, the processing of donations from employees of the organization, and the execution of contracts with healthcare providers. Some operational elements, though, tend to be a little different from other countries, which ultimately affect the way BJPS operates. The health ministry shall establish the quality of operation, treatment, and reference to ensure the standardization of primary care providers [13].
However, it is important to note that a complicated, multidimensional mechanism requiring an appropriate degree of uncertainty, is the way to make decisions and implement a national health policy [9].

\subsection{NPM Concerns on BPJS}

The NPM has a strong impact on BPJS in the formation of BPJS to comply with Universal Healthcare Standards and, indeed, to improve the power of the government [10]. The first concerns the overuse of financial steps to schedule and handle BPJS. The BPJS model has been highly influenced by the policies and activities of the capitalist sector. A prominent social activist said that the government has ceded the citizens their obligations and duties and handed them over to a corporation in the private sector. Thus, the State delegated the fate of working citizens to third-parties and business interests. In 2011, the Head of State Businesses announced that the Ministry of Finance, World Bank, IMF, $\mathrm{ADB}$, and ILO had formed the BPJS in a Neo-Liberal Approach [10].

Secondly, while the BPJS's five missions embody universal healthcare values, the BPJS's activities are governed by NPM principles, and even worse [10]. Government Regulation Number 86 Year 2013, for example, specifies that anyone who refuses to pay their BPJS premiums cannot have access to public facilities such as the procurement of driver's licenses, passports, and school entries for children. Despite this tactic, people might pay BPJS premiums, but, as a National Member of Parliament claimed, they are against the human rights of other citizens.

Thirdly, BPJS represents the private-sector model of its activities focused on regulatory procedures. This requires the separation of duties and comprehensive administrative oversight. The Board of Directors of BPJS is compatible with the financial management standards used by the private-sector, including governance, operating accounts, budgets and financial statements, and accounting procedures. Finally, some key aspects of BPJS procedures are consistent with the strategies practiced by private healthcare organizations in business accounting structures including balance sheets, cash balances, asset and liabilities, tracking and reporting of deficits [10].

\section{METHOD}

This research used a qualitative analysis approach to assess and evaluate the opinions of Indonesian Government and people by assessing the impact of the implementation of BPJS to answer the research concerns. To improve the precision and reliability, any qualitative analysis involves the triangulation of facts by analyzing the information from multiple sources and then using it to provide a clear interpretation of the observation. We have followed the major standards proposed, which include: 1) Primary document or secondary document authenticity; (2) Credibility of the details in the document; and (3) The reliability of document-source creators, for enhancement of the quality of the text sources used in this research. These 
provisions have helped to conduct a thorough and comprehensive analysis of the history of the National Healthcare Insurance Scheme, legal sources and legislative records, newspaper coverage, and other related details. This methodology is popular in many countries with previous NPM effect studies on the healthcare system [11] [14].

\section{RESULTS AND DISCUSSIONS}

\subsection{The Number of Services Provided}

The introduction of BPJS has certainly and tremendously increased the number of patients in the scheme. For instance, the service delivered in 2018 was 233 million; in 2017 it was 223 million. Figure 2 also shows that the number of services delivered in 2018 rose from 92.3 million in 2014 to 230 million in 2018 . The study supports the claim that Indonesia has been able to use healthcare services through the Universal Health Management Mechanism [15]. When people got ill, the figures rose by $8 \%$ and rose by $5 \%$ globally.

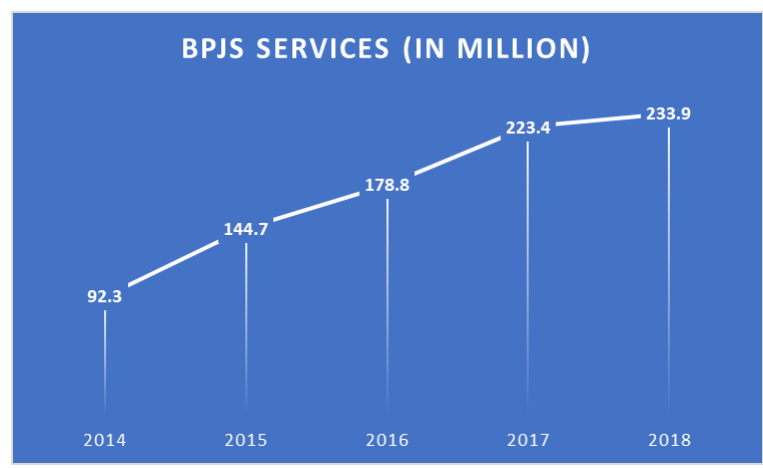

Figure 2 BPJS Services

Source: https://bpjs-kesehatan.go.id/bpjs/

However, there was a shift in the quality standard in the growth of the number of patients and treatment rendered. In the BPJS scheme, the costs of hospital services are not covered by the BPJS system. It does not refer to medicines received in other countries, surgical treatment, infertility treatment, orthodontics, opioid or toxic disorder, herbal medicine, experimental treatment, contraception, cosmetics, foodstuffs, and formulations. BPJS also refers to emergency treatment in the event of natural catastrophes, epidemics, accidents, or emergencies [10].

\subsection{The Structural Challenges and Outcomes}

While the number of healthcare facilities offered by BPJS is significantly greater, there are major challenges and these problems are preventing the long-term financial stability and longevity of the national healthcare system. We can see that the root of the problems lies in the powerful position of policy-makers and political powers, who do not grasp the technological activities of BPJS from a medical, economic, or financial point of view. This also means that the formation of BPJS did not lead the government to raise public expenditure on services needed for a growing number of patients or to make medical practitioners available. A broad variety of phenomena reflects this condition. The BPJS reports that it is responsible for developing and delivering quality and accessible healthcare in a high deficit and inadequate budgetary expenditure funding. BPJS faced growing deficits last year in tandem with low government spending in the healthcare sector [10]. For instance, in 2015, the deficit was Rp 5.7 billion $(\$ 400$ million). This figure rose in 2016 and 2017 to Rp 9.7 trillion and $\mathrm{Rp} 9.8$ trillion (\$700 million). The BPJS structural losses between 2014 and 2018 are seen in Figure 3. Researchers conclude that the disparities are due to a lack of discretionary resources for spending in public health. It should be remembered that the share of health spending in the government's budget is very small relative to other comparable developed-countries.

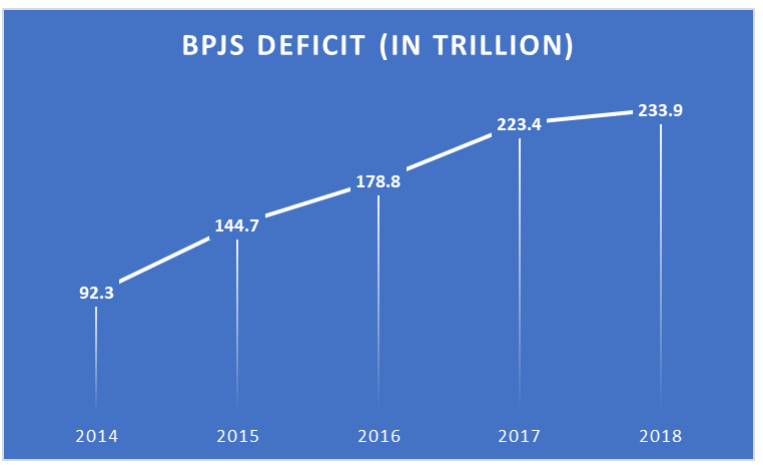

Figure 3 BPJS Deficit

Source: https://bpjs-kesehatan.go.id/bpjs/

The shortage of government funding to support BPJS is not necessarily due to the lack of money, which is ironic. The BPJS's debt is relatively low in contrast to other government debts and is a result of the government economic policy in the last ten years [10]. This truth confirms what critical scholars have said [7]-[9], that the object of government budgets in a spirit of neo-liberalism is not to respond to people's basic needs, but to pay what is owed to the creditors and bankers in the world. Compared to the annual government budgets for foreign creditors, the allocation of Indonesian national budgets to credit agencies is drastically reduced. This is not a special problem for Indonesia, and public-health funding for the Greek and Latin American countries is also low [7]-[10].

\subsection{The Resistance from Physicians}

Neo-liberalism, which promotes the usage of private principles to finance and serve public-health programs, has undesirable effects, as recent reports have demonstrated in other nations. This involves the opposition from surgeons, dentists, and experts in medicine. Since 2015, Indonesia has maintained its opposition to the policies of BPJS by medical professionals [10]. For e.g., CNN Indonesia reported in 2015 that doctors treating patients in the BPJS system often 
complained that the government's expenses per member were charged cheaply. One of the reasons for the issue was the Unified Indonesian Doctors Campaign. The BPJS system pays the doctors, lower than the parking costs. In 2016, hundreds of doctors from the Unified Indonesian Drug staged a violent rally before the State-Palace on 29 February 2016. The frustration continued. They encouraged the government to change BPJS by raising fairer-rates to healthcare practitioners and other doctors. Mass-media also said that the Indonesian Dental Association (PDGI) targeted 35,000 dentists across Indonesia with a possibility of retirement from the BPJS alliance. The study found that dentists appear to be impaired by Health Minister Regulation Number 59. This includes regular healthcare premiums as compulsory health-insurance programmers were introduced. They said that if the government couldn't boost the fees for dentists, our BPJS agreements would be torn down.

\subsection{The Politicians' Tendency}

The essence and impacts of NPMs are generally affected by the policy context and by what the national health-sector needs other political parties to do. Furthermore, we presume that this point often concerns the answers of those responsible for any issue that applies to the implementation of the BPJS. Then, the Jokowi government's reaction to the deficits of the BPJS, accusing BPJS of its failure to pay its debts, is an example of a strategy to reduce the electoral risks of the leading group. The study emphasized the inability of the government to create a better strategy and funding model for universal healthcare system to function by the commitment of the BPJS Law Number 40 and the 2014 political campaign of President Jokowi [10]. The President blamed the mechanism conflicts with the fact that the President also had the responsibility for the nature and function of the BPJS and that the government agreed on monthly-rates through the Health Ministry. The President's declaration was then refused by a member of the House of Representatives. Instead of recommending that the deficit of BPJS should be decided by the Health Minister and the BPJS Management, the President should have a solution. BPJS, under a close control by the President, is a public-law authority.

\section{CONCLUSION}

From the questions in this research, a range of hypotheses could be taken. We concluded that the BPJS policy-making is mainly driven by national elite and foreign bodies, without properly addressing the main obstacles for the viability of the universal health-system in the longer-term. Thus, the composition and actions of BPJS are influenced by the essence of BPJS. Thus, the BPJS's institutionalization faces a range of challenges, including the low-premium climate, a rise in deficits, an opposition from medical practitioners and the political practice of blaming the insurance industry which has initiated the government for failing to pay hospital and prescription expenses.

Our results reinforce the past experiments that have had unforeseen consequences on the institutionalization of NPM, including increasing unfair access to people with low and high incomes [1] and the resistance from doctors and city rivals [3]. Also understandable are the challenges inherent from Jakarta's dense population to Papua's limited population in institutionalizing the Universal Healthcare Insurance Scheme for too big (over a quarter of a billion) and diverse (17,000 islands). The government should also ensure that the BPJS goals are successful in delivering healthcare and are directed towards ensuring that all customers have a uniform service.

In our review of the institutional operational structure, the BPJS's vital position as a state-agent for universal healthcare and evolving challenges, we make a variety of recommendations to enhance the viability and efficacy of the BPJS operations. No doubt BPJS is a post-Suharto organization in Indonesia, which can theoretically improve the society. It is important to take notice of the statement that countries with a comprehensive package of health reforms and a direct road to NPM transition can perform better than do countries with a just partial one [16]. The achievement of ambitious targets can lead to possible future deception and issues with what can be accomplished with a more-restricted target. It can even help to severely misallocate and misuse the capital [10]. Based on the recent problems faced by BPJS and the experience of other countries like Australia or the United Kingdom, we propose the following: the transformation of primary position of the BPJS, automatic membership of all residents, simplification and reorientation of BPJS coverage, and taxation.

The experiments include inconveniences. All of these drawbacks were that the representatives of various social or economic classes were not present. We recommend that prospective research groups should be analytically established to decide whether the conflicts in opinion exist about the NPM changes in the healthcare sector.

\section{ACKNOWLEDGMENT}

This essay is part of a community-paper study on the subjects and research of management accounting, University of Indonesia - PhD Program in Accounting. We thank Dr. Ancella A. Hermawan for her contribution to the public-sector concept of NPM.

\section{REFERENCES}

[1] E. S. Rotarou and D. Sakellariou, "Neoliberal reforms in health systems and the construction of longlasting inequalities in health care: A case study from Chile," Health Policy (New. York)., 2017, doi: 


\subsection{6/j.healthpol.2017.03.005.}

[2] N. Homedes and A. Ugalde, "Why neoliberal health reforms have failed in Latin America," Health Policy (New. York)., 2005, doi:

10.1016/j.healthpol.2004.01.011.

[3] P. Pushkar, "NHS Activism: The Limits and Potentialities of a New Solidarity," Med. Anthropol. Cross Cult. Stud. Heal. Illn., 2019, doi: 10.1080/01459740.2018.1532421.

[4] A. Maharani, D. Femina, and G. Tampubolon, "Decentralization in Indonesia: Lessons from cost recovery rate of district hospitals," Health Policy Plan., 2015, doi: 10.1093/heapol/czu049.

[5] Suryanto, V. Plummer, and M. Boyle, "Healthcare System in Indonesia," Hosp. Top., 2017, doi: 10.1080/00185868.2017.1333806.

[6] J. Mei and I. Kirkpatrick, "Public hospital reforms in China: towards a model of new public management?," International Journal of Public Sector Management. 2019, doi: 10.1108/IJPSM-03-20180063.

[7] M. Gold, "Pathways to the use of health services research in policy," Health Serv. Res., 2009, doi: 10.1111/j.1475-6773.2009.00958.x.

[8] M. Karanikolos and A. Kentikelenis, "Health inequalities after austerity in Greece," International Journal for Equity in Health. 2016, doi:

10.1186/s12939-016-0374-0.

[9] E. Pavolini, E. Kuhlmann, T. I. Agartan, V. Burau, R. Mannion, and E. Speed, "Healthcare governance, professions and populism: Is there a relationship? An explorative comparison of five European countries," Health Policy (New. York)., 2018, doi:

10.1016/j.healthpol.2018.08.020.

[10] E. Erniaty and H. Harun, "Understanding the impacts of NPM and proposed solutions to the healthcare system reforms in Indonesia: The case of BPJS," Health Policy Plan., 2020, doi:

10.1093/heapol/czz165.

[11] G. Walt, E. Pavignani, L. Gilson, and K. Buse, "Health sector development: From aid coordination to resource management," Health Policy and Planning. 1999, doi: 10.1093/heapol/14.3.207.

[12] V. Wiseman et al., "An evaluation of health systems equity in Indonesia: Study protocol," Int. J. Equity Health, 2018, doi: 10.1186/s12939-018-0822-0.
[13] R. Agustina et al., "Universal health coverage in Indonesia: concept, progress, and challenges," The Lancet. 2019, doi: 10.1016/S0140-6736(18)31647-7.

[14] M. George, "The effect of introducing new public management practices on compassion within the NHS.," Nurs. Times, 2017.

[15] Y. Vidyattama, R. Miranti, and B. P. Resosudarmo, "The Role of Health Insurance Membership in Health Service Utilisation in Indonesia," Bull. Indones. Econ. Stud., 2014, doi: 10.1080/00074918.2014.980380.

[16] R. Andrews, M. J. Beynon, and A. McDermott, "Configurations of New Public Management reforms and the efficiency, effectiveness and equity of public healthcare systems: a fuzzy-set Qualitative Comparative Analysis," Public Manag. Rev., 2019, doi:

10.1080/14719037.2018.1561927. 